Slobodan Beljanski

Advokatska komora Vojvodine

\title{
SUD U SLUŽBI POLITIKE *1 Slučaj izručenja Dževdeta Ajaza
}

\section{POSTUPAK IZRUČENJA}

Odluka Komiteta protiv torture Ujedinjenih nacija kojom se utvrđuje da je Srbija, izručujući Dževdeta Ajaza Turskoj krajem 2017. godine, povredila odredbe čl. 3. i 22. Konvencije protiv torture i drugih surovih, neljudskih ili ponižavajućih kazni i postupaka, ${ }^{2}$ ponovo je skrenula pažnju na ovaj slučaj. Korisno je ukazati na njegove činjenične i pravne aspekte.

Državljanina Republike Turske, Dževdeta Ajaza (Cevdet Ayaz), inače etničkog Kurda, radnici Policijske stanice Mali Zvornik su po Interpolovoj poternici lišili slobode 30.11. 2016. godine i istog dana ga priveli sudiji za prethodni postupak Višeg suda u Šapcu. Saslušan je u prisustvu branioca po službenoj dužnosti, uz pomoć lica za koje je konstatovano da „poznaje turski jezik i preko koga će se obaviti komunikacija". U zapisniku je navedena Ajazova izjava da zna zbog čega mu je u Turskoj suđeno, da je zbog toga napustio Tursku 30. 3. 2016. godine, da se plaši izdržavanja izrečene kazne i da bi želeo da stalno bude u Srbiji.

${ }^{*}$ Rad je primljen 15. 9. 2019, a prihvaćen je za objavljivanje 30. 10. 2019. godine.

${ }^{1}$ Delovi ovog eseja, ranije su učinjeni dostupnim javnosti. Dostupno na: https://pescanik.net/podrugivanje-pravu-slucaj-izrucenja-dzevdeta-ajaza/

${ }^{2}$ Odluka Komiteta protiv torture UN po žalbi br. 857/2017, doneta na 67. sednici Komiteta, održanoj od 22. jula do 9. avgusta 2019. godine. 
Ambasada Republike Turske u Beogradu dostavila je 26. 12. 2016. godine našem Ministarstvu pravde notu uz koju je priložila molbu za izručenje Ajaza radi izdržavanja preostalih 10 godina i 5 meseci od ukupne kazne zatvora od 15 godina izrečene pravnosnažnom presudom Krivičnog suda za teška krivična u Dijarkbakiru (Turska) br. 2012/646 od 27. 11. 2012. godine. Navedeno je da je osuđen zbog krivičnog dela iz čl. 314. st. 1. Krivičnog zakona Turske br. 5237, odnosno zbog osiguranja smeštaja za one koji su počinili organizovani kriminal.

Nakon saslušanja, sudija za prethodni postupak odredio je Ajazu pritvor u trajanju do 18 dana, a najduže do izvršenja odluke o izručenju. Pritvor je kasnije produžavan u zakonom predviđenim rokovima, sve do isteka najdužeg mogućeg trajanja od godinu dana, tj. do 30. 11. 2017. godine.

Rešenjem Višeg suda u Šapcu br. 1 Kre. 2/17. od 19. 1. 2017. godine utvrđeno je da su ispunjene pretpostavke za izručenje. U rešenju se pominje presuda suda Elazig i osuda za krivično delo ,prikrivanje lica koja su učestvovala u organizovanom kriminalu".

Po žalbi angažovane braniteljke, advokatkinje Ane Trkulje iz Beograda, Apelacioni sud u Novom Sadu je rešenjem Kž Kre. 7/17. od 23. 2. 2017. godine ukinuo prvostepeno rešenje, ukazujući da nije obezbeđen odgovarajući prevodilac i da nije utvrđeno o kom se krivičnom delu po zakonu Republike Turske radi.

I novim rešenjem Višeg suda u Šapcu br. 1 Kre. 2/17. od 17. 3. 2017. godine utvrđeno je da su ispunjene pretpostavke za izručenje. U rešenju se ističe da je Ajaz osuđen zbog krivičnog dela naoružana organizacija iz čl. 314. st. 1. turskog Krivičnog zakona br. 5237, a da se iz opisa dela vidi da je ,,zajedno sa drugim licima oformio organizaciju koja je preduzimala aktivnosti upravljene na uništenje postojećeg poretka Republike Turske, u cilju nacionalne nezavisnosti i oslobođenja Kurdistana sa revolucionarnim konceptom”.

Na sednici veća Apelacionog suda u Novom Sadu, održanoj 12. 4. 2017. godine, Ajaz je izjavio da je on predsednik partije za grad u kome živi - Slobodarske partije Kurdistana, da je to legalno registrovana partija, da nikad nije bio član neregistrovane partije, pa ni partije Revolucionarnih Kurdistana. Istakao je da je bio podvrgnut torturi u policiji u Turskoj, jer je bio izložen strujnim udarima, onemogućavanju normalnog disanja i drugim vidovima zlostavljanja, pa je pod takvim okolnostima potpisao četiri reda teksta u kome priznaje krivično delo, iako ga nije učinio. Pomenuo je i odluku suda u Strazburu kojom je svojevremeno utvrđeno kršenje Evropske konvencije na njegovu štetu.

Apelacioni sud u Novom Sadu je rešenjem Kž Kre. 13/17. od 12. 4. 2017. godine ponovo ukinuo prvostepeno rešenje, još jednom ukazujući da nije obezbeđen odgovarajući prevodilac i da nije utvrđeno o kom se krivičnom delu radi. Naime, u molbi za izručenje navedeno je da se radi o krivičnom delu 
osiguranje smeštaja za one koji su počinili organizovani kriminal, u pobijanom rešenju se govori o krivičnom delu naoružana organizacija, a u opisu krivičnog dela iz čl. 314. st. 1, za koje je osuđen, reč je o prikrivanju lica koja su učestvovala u organizovanom kriminalu.

Rešenjem Višeg suda u Šapcu br. 1 Kre. 2/17. od 12. 10. 2017. godine po treći put je utvrđeno da su ispunjene pretpostavke za izručenje. Navedeno je da je Ajaz osuđen zbog krivičnog dela naoružana organizacija iz čl. 314. st. 1. turskog Krivičnog zakona br. 5237. Utvrđeno je da je krivično delo za koje je osuđen kažnjivo i po domaćem zakonu kao krivično delo udruživanje radi protivustavne delatnosti iz čl. 319. st. 1. u vezi sa čl. 309. st. 1. KZ RS. Navodi se da je sud zapazio kontradiktornosti koje postoje između sadržaja molbe za izručenje, s jedne strane, i podataka u dostavljenoj dokumentaciji s druge strane, ali da se, po oceni suda radi o tehničkim greškama kao očiglednim posledicama neadekvatnih prevoda od strane lica koja izvesno ne poseduju odgovarajuća znanja o terminologiji krivičnog prava. Po shvatanju suda, to ne predstavlja prepreku za zauzimanje pravilnog stava o ispunjenosti pretpostavki za izručenje.

Ajazova braniteljka je 20. 10. 2017. godine sudu dostavila presudu Evropskog suda za ljudska prava donetu 22. 6. 2006. godine po predstavci br. 11804/02 (pravnosnažna 22. 9. 2006), kojom je utvrđeno da je Turska, pored ostalih i na Ajazovu štetu, povredila čl. 5. st. 3. i 4. Evropske konvencije za zaštitu ljudskih prava i osnovnih sloboda, u postupku koji je prethodio donošenju presude zbog čijeg izvršenja se traži izručenje (višednevno zadržavanje u policijskom pritvoru bez sudske kontrole, uskraćivanje prava na efikasan i delotvoran pravni lek).

Na sednici veća pred Apelacionim sudom u Novom Sadu 15. 11. 2017. godine Ajaz je izjavio da na suđenje u Turskoj nije bio pozvan i da je za izrečenu kaznu saznao kasnije. Ponovio je da je u Turskoj bio podvrgnut torturi i ukazao na probleme sa tumačem pred prvostepenim sudom.

Apelacioni sud u Novom Sadu je rešenjem Kž Kre. 30/17. od 22. 11. 2017. godine ${ }^{3}$ ponovo uvažio žalbu braniteljke i treći put ukinuo prvostepeno rešenje. Našao je da je osuđenom uskraćeno pravo da upotrebljava svoj jezik i da na svom jeziku prati tok postupka. Ukazao je na manjkavosti prevoda dokumentacije koja je dostavljena od strane Turske. Prihvatio je navode žalbe da su prevodi spisa ispisani delom ćiriličnim a delom latiničnim pismom, da su pojedine rečenice lišene smisla, a pojedini paragrafi nerazumljivi i nejasni, kao i da je deo spisa sa naslovom „Turski krivični zakon” u celosti preveden na makedonski jezik, zbog čega se ne može prihvatiti obrazloženje prvostepenog suda

${ }^{3}$ Istog dana je Komisija za azil odlukom Až-37-1/17. od 22. 11. 2017. godine konačno odbacila Ajazov zahtev za azil. 
da je reč o tehničkim greškama. Ocenio je da prvostepeni sud objektivno nije bio u mogućnosti da se upusti u razmatranje da li su zakonske pretpostavke za izručenje ispunjene, budući da lice čije se izručenje traži nije saslušano putem oficijelnog tumača za turski jezik, niti je sud bio u prilici da na zvaničnom jeziku postupka izvrši uvid u spise dostavljene od strane Turske. Naložio je da se u ponovljenom postupku obezbedi adekvatan prevod pomenute dokumentacije da bi se jasno moglo utvrditi o kom se krivičnom delu radi.

Na sednici veća Višeg suda u Šapcu 30. 11. 2017. godine, na kojoj je konačno obezbeđeno prisustvo stalnog sudskog prevodioca za turski jezik, Ajaz je izjavio da je za osudu na 15 godina zatvora naknadno saznao, da na prvom saslušanju nije razumeo šta se govori, da se plaši za svoju bezbednost ukoliko bude izručen i da mu je u pritvoru u Turskoj priznanje iznuđeno zlostavljanjem.

Zbog isteka maksimalno dozvoljenog trajanja pritvora, istog dana, 30. 11. 2017. godine, rešenjem Višeg suda u Šapcu 1 Kre. 2/17. Ajazu je pritvor ukinut i naređeno je da se on, uz zabranu napuštanja boravišta na teritoriji Banje Koviljače i oduzimanje putne isprave, odmah pusti na slobodu. Umesto da bude pušten, međutim, sproveden je u Prihvatilište za strance u Padinskoj skeli. O ovome nije doneto nikakvo rešenje, nego je v. f. predsednika Višeg suda u Šapcu uputio 30. 11. 2017. godine Prihvatilištu običan dopis u kome podvlači da je nužno da Ajaza smeste u svoju ustanovu, jer Centar za azil u Banji Koviljači navodno nema smeštajne kapacitete, a radi se turskom državljaninu kurdske nacionalnosti osuđenom za teško krivično delo protiv državnog poretka. Praktično, Ajaz je uprkos ukidanju pritvora i dalje ostao lišen slobode, bez ikakvog pravnog osnova i ikakve sudske odluke. Urgentni zahtevi njegove braniteljke da se poštuje rešenje o ukidanju pritvora nisu urodili plodom. ${ }^{4}$

Odmah potom, rešenjem Višeg suda u Šapcu br. 1 Kre. 2/17. od 1. 12. 2017. godine i četvrti put je utvrđeno da su ispunjene pretpostavke za izručenje. U rešenju se navodi da to što se u prevodu teksta podnete molbe za izručenje pominje da je Ajaz osuđen za krivično delo pružanja smeštaja izvršiocima krivičnih dela na organizovan način iz čl. 314. st. 1. Krivičnog zakona Republike Turske broj 5237, a u naknadno dostavljenom prevodu presude da je osuđen zbog krivičnog dela naoružana organizacija iz čl. 168. st. 1. Krivičnog zakona Republike Turske br. 765, ne predstavlja prepreku za pravilnu analizu činjenica i okolnosti koje su od značaja za zaključak da su ispunjene pretpostavke za izručenje.

${ }^{4} \mathrm{O}$ pritvoru i postupku za dobijanje azila više u članku Jasne Mitić, Draška Đurovića i autorke koja nije želela da otkrije identitet: Izgubljeni u prevodu - izručenje Kurda Dževdeta Ajaza Republici Turskoj, blog Advokatske komore Srbije, 8. 1. 2019; https://blog.aks.org.rs/ izgubljeni-u-prevodu-izrucenje-kurda-dzevdeta-ajaza-republici-turskoj/ 
Povodom nove žalbe braniteljke Apelaciono javno tužilaštvo u Novom Sadu izjasnilo se da je prvostepeni sud ovom prilikom obezbedio odgovarajućeg tumača, ali da nije postupio u skladu sa nalozima drugostepenog suda u pogledu prevoda dokumentacije koja je dostavljena iz Turske, pa je predložilo da prvostepeno rešenje bude ukinuto.

Na sednici veća Apelacionog suda u Novom Sadu 14. 12. 2017. godine Ajazova braniteljka je iznela da ju je Komitet protiv torture UN, u aktu koji je priložila u originalu i overenom prevodu, obavestio da je primio njenu pritužbu i da je, preko svog predsedavajućeg, odlučio da od države potpisnice, u ovom slučaju Republike Srbije, traži da se uzdrži od izručenja dok Komitet žalbu razmatra.

Apelacioni sud u Novom Sadu je rešenjem br. Kž Kre. 64/17. od 14. 12. 2017. godine odbio žalbu braniteljke i potvrdio prvostepeno rešenje. Ukazao je da je za ocenu da li se radi o političkom krivičnom delu nadležan ministar pravde, a ne sud.

Ajazova braniteljka je u dopisu od 14. decembra 2017. obavestila Ministarstvo unutrašnjih poslova, Direkciju za policiju i Upravu granične policije da je Komitet protiv torture UN 11. decembra 2017. godine izdao zahtev za preduzimanje privremenih mera u vezi sa Ajazovim predmetom i da bi njegovim izručenjem u Tursku bile prekršene međunarodne obaveze. Isti dopis je 18. decembra 2017. godine dostavljen Ministarstvu pravde.

Rešenjem ministra pravde br. 713-01-05190/2016-08 od 15. 12. 2017. godine dozvoljeno je Ajazovo izručenje. Ministar pravde se u rešenju nije upuštao u pitanja: da li se radi o političkom krivičnom delu, da li je licu čije se izručenje traži suđeno u odsustvu i da li tom licu u državi molilji preti opasnost od torture.

Dževdet Ajaz je izručen Turskoj 25. 12. 2017. godine.

\section{RELEVANTNO PRAVO}

Za materijalni i procesni aspekt ekstradicije u ovom slučaju relevantno pravo predstavljaju: Evropska konvencija o ekstradiciji; Ustav Republike Srbije; Zakon o međunarodnoj pravnoj pomoći u krivičnim stvarima (ZMPPKS); Ugovor između Republike Srbije i Republike Turske o izručenju; Konvencija protiv torture i drugih surovih, neljudskih ili ponižavajućih kazni i postupaka; Evropska konvencija za zaštitu ljudskih prava i osnovnih sloboda; Međunarodni pakt o građanskim i političkim pravima; Krivični zakonik RS; Zakonik o krivičnom postupku RS; Zakon o organizaciji i nadležnosti državnih organa u suzbijanju organizovanog kriminala, terorizma i korupcije; izvod iz Krivičnog 
zakona Republike Turske; praksa Evropskog suda za ljudska prava, Komiteta protiv torture UN, Ustavnog suda i sudova redovne nadležnosti Republike Srbije.

Ustavom je propisano da su opšteprihvaćena pravila međunarodnog prava i potvrđeni međunarodni ugovori sastavni deo pravnog poretka Republike Srbije i da se neposredno primenjuju, a da se odredbe o ljudskim i manjinskim pravima tumače u korist unapređenja vrednosti demokratskog društva, saglasno važećim međunarodnim standardima ljudskih i manjinskih prava, kao i praksi međunarodnih institucija koje nadziru njihovo sprovođenje (čl. 16. st. 2. i čl. 18. st. 2. i 3).

Evropskom konvencijom o ekstradiciji (čl. 3), Ugovorom između Republike Srbije i Republike Turske o izručenju (čl. 3), i ZMPPKS (čl. 7. st. 1. t. 4) predviđeno je da se izručenje neće odobriti za dela koja su prema oceni zamoljene države politička krivična dela ili dela povezana sa političkim krivičnim delom, odnosno ako je u zamoljenoj državi s razlogom zasnovano uverenje da je izdavanje zatraženo radi gonjenja ili kažnjavanja zbog rasne pripadnosti, vere, nacionalnosti, političkih ubeđenja, pa čak i ako bi položaj traženog lica iz navedenih razloga mogao biti samo pogoršan.

U ZMPPKS je propisano da:

- ukoliko je lice čije se izručenje traži osuđeno u odsustvu neophodno je da država molilja dâ garancije da će postupak biti ponovljen u njegovom prisustvu (čl. 16);

- država molilja ima obavezu da zahtev za pružanje pravne pomoći kao i sva prateća pismena dostavi sa prevodom na jezik zamoljene države ili na engleski jezik, da prevod mora biti overen od strane sudskog tumača, i da će zahtev koji nije podnet u skladu s odredbama ovog zakona biti vraćen radi ispravke ili dopune uz određivanje roka koji ne može biti duži od 2 meseca (čl. 5) ${ }^{5}$

- ako tim zakonom nije drukčije određeno, u postupku pružanja međunarodne pravne pomoći shodno se primenjuju odredbe Zakonika o krivičnom postupku i zakona kojima se uređuje organizacija i nadležnost sudova i javnih tužilaštava (čl. 12).

Konvencijom protiv torture i drugih surovih, neljudskih ili ponižavajućih kazni i postupaka države članice su se obavezale da neće proterati, vratiti ili izručiti osobu drugoj državi ako postoje ozbiljni razlozi za sumnju da može biti podvrgnuta torturi. Da bi utvrdili postojanje takvih razloga nadležni organi su dužni da vode računa o svim relevantnim okolnostima, uključujući eventualno postojanje niza sistemskih, ozbiljnih, očitih ili masovnih povreda prava čoveka u toj državi (čl. 3).

\footnotetext{
${ }^{5}$ Analognu odredbu sadrži čl. 23. Evropske konvencije o ekstradiciji.
} 
U praksi Komiteta protiv torture UN zauzet je stav da postojanje obrasca grupnih i masovnih kršenja ljudskih prava nije dovoljno za zaključak o opasnosti od torture, već je potrebno utvrditi postojanje ličnog rizika, odnosno potrebno je da postoje značajni osnovi za verovanje da će podnosilac žalbe lično biti podvrgnut torturi po povratku u državu izručenja. Ti osnovi moraju prevazilaziti samo teoretsku šansu i sumnju, mada rizik ne mora biti izuzetno visokog stepena verovatnoće, ali mora biti predvidiv, stvaran i kao što je već napomenuto, uperen lično prema licu čije se izručenje traži. ${ }^{6}$ Takođe, prema praksi Komiteta, i u slučaju da je podnosilac žalbe već bio podvrgnut mučenju potrebno je dokazati postojanje rizika da će takvo postupanje prema njemu biti ponovljeno. Činjenično stanje u Ajazovom predmetu, slično je onom u predmetu F. K. (takođe pripadnik kurdske etničke grupe), u kome je Komitet utvrdio da je Danska povredila čl. 3. Konvencije. ${ }^{7}$

Evropski sud za ljudska prava, u vezi sa čl. 3. Evropske konvencije, primenjuje u praksi opšte principe za ocenu postojanja stvarne opasnosti od zlostavljanja, o prošlom zlostavljanju kao indikatoru opasnosti i o pripadnosti ciljnoj grupi lica o čijem se izručenju radi. Ustanovio je da izručenje ili deportacija nekog lica može otvoriti pitanje odgovornosti države kad postoje ozbiljni razlozi za verovanje da će podnosilac predstavke u državi izručenja biti podvrgnut postupanju protivnom čl. 3. Konvencije. ${ }^{8}$

Za povrede čl. 5. st. 3. i 4. Evropske konvencije, u presudi koja se odnosi na Ajaza, Evropski sud se pozvao na dve svoje ranije donete odluke. ${ }^{9}$

U skladu sa čl. 6. Evropske konvencije za zaštitu ljudskih prava i osnovnih sloboda, u sklopu prava na pravično suđenje garantuje se i pravo okrivljenog na upotrebu svog jezika u postupku, kao i pravo na besplatno prevođenje. U čl. 32. st. 2. našeg Ustava propisano je da se svakome jemči pravo na besplatnog prevodioca ako ne govori ili ne razume jezik koji je u službenoj upotrebi u sudu. Zakonikom o krivičnom postupku propisano je da stranke, svedoci i druga lica koja učestvuju u postupku imaju pravo da u toku postupka upotrebljavaju svoj jezik i pismo, a ako se postupak ne vodi na njihovom jeziku i ako, nakon pouke o pravu na prevođenje, ne izjave da znaju jezik na kome se postupak vodi i da se odriču prava na prevođenje, obezbediće im se na teret budžetskih sredstava prevođenje onoga što oni ili drugi iznose, kao i prevođenje isprava i drugog pisanog dokaznog materijala. Prevođenje oba-

${ }^{6}$ Odluka od 8. 11. 2013. godine po pritužbi br. 426/2010.

${ }^{7}$ Odluka od 23. 11. 2015. godine po pritužbi br. 580/2014.

${ }^{8}$ Chahal v. Ujedinjenog Kraljevstva, 22414/93, 15. 11. 1996; Ahmed v. Austrije, 25964/94, 17. 12. 1996; Saadi v. Italije, 37201, 28. 2. 2008; Sufi and Elmi v. Ujedinjenog Kraljevstva, 8319/07, 11449/07, 28. 6. 2011; J. K. i drugi v. Švedske, 59166/12, 23. 8. 2016.

9 Öcalan protiv Turske, Veliko veće, 46221/99, 12. 5. 2005; Brogan i drugi protiv Ujedinjenog Kraljevstva, 11234/84, 11209/84, 29. 11. 1988. 
vlja prevodilac, koji mora položiti zakletvu da će verno preneti pitanja koja se okrivljenom upućuju i izjave koje on bude davao (čl. 11. i 87). ${ }^{10}$

U Zakonu o organizaciji i nadležnosti državnih organa u suzbijanju organizovanog kriminala, terorizma i korupcije propisano je da je za postupanje u predmetima organizovanog kriminala nadležan Viši sud u Beogradu, kao prvostepeni, za teritoriju Republike Srbije. Kada se radi o krivičnom delu organizovanog kriminala, prema domaćoj sudskoj praksi, za odlučivanje o ispunjenosti pretpostavki za izručenje osumnjičenog stranoj državi nadležan je Viši sud u Beogradu kao prvostepeni sud za teritoriju Republike Srbije. ${ }^{11}$

\section{PRAVNA OCENA}

U Ajazovom predmetu bilo je potrebno, pored ostalih pretpostavki za izručenje, utvrditi:

- za koje krivično delo je osuđen u Turskoj, da li se radi o krivičnom delu organizovanog kriminala i da li to delo spada u politička krivična dela;

- da li je u Turskoj prema Ajazu primenjivana tortura u vezi sa postupkom u kome je osuđen pravnosnažnom presudom i da li mu u slučaju izručenja preti ozbiljna opasnost da će zlostavljanje biti ponovljeno;

- da li je Ajazu u Turskoj suđeno u odsustvu i da li postoje garancije da će se, u slučaju izručenja, suđenje ponoviti.

Uslov za odgovor na sva ova pitanja je stručan, potpun i tančan prevod dokumentacije koju je dostavila država molilja, sačinjen od ovlašćenog i zakletog prevodioca, i prevođenje izjava, saopštenja i pitanja u komunikaciji između Ajaza i službenih lica u Srbiji, sa turskog na srpski i sa srpskog na turski jezik, putem ovlašćenog i zakletog sudskog tumača.

Iz prethodno iznetih podataka vidi se da tokom celokupnog trajanja pritvora u periodu od punih godinu dana, sve do završne faze sudskog dela postupka za izručenje, tj. do sednice veća pred Višim sudom u Šapcu 30. 11. 2017. godine, pred tim sudom Ajazu nije bio obezbeđen ovlašćeni prevodilac za turski jezik. Takođe, vidi se da država molilja, uprkos svojoj obavezi, nije

${ }^{10}$ Pozivajući se na praksu Evropskog suda za ljudska prava (Mamatkulov \& Askarov v. Turkey, 46827/99. i 46951/99, 4. 2. 2005), Ustavni sud tumači izraz ,suđenje” veoma usko, isključujući iz njegovog značenja odluke koje se, rationae materiae, ne mogu dovesti u vezu sa povredom prava na pravično suđenje jer se u njima ne odlučuje o osnovanosti sumnje ili o optužbi. Zbog toga je odbacio ustavnu žalbu protiv pravnosnažne odluke suda da su ispunjeni uslovi za izručenje (Ǔ̌-8975/2013).

${ }^{11}$ Viši sud u Kraljevu Kv 59/17. od 21. 3. 2017. godine i Apelacioni sud u Kragujevcu, Kž2 202/17. od 30. 3. 2017. godine. 
dostavila odgovarajući prevod presuda i pratećih isprava. Sud zamoljene države imao je na raspolaganju prevod prvostepene i drugostepene presude i druge dokumentacije sastavljen od strane lica koje, iako sudeći po nečitkom pečatu ima status prevodioca, očigledno ne zna dobro ni turski ni srpski jezik, jer je prevod pun pravopisnih, gramatičkih, jezičkih i smisaonih grešaka, i predstavlja mešavinu makedonskog i srpskog jezika. U spisima postoji i drugi prevod presuda, ali se na njemu (bar na kopiji koja nam je bila dostupna), ne vide ime, potpis i pečat prevodioca.

Apelacioni sud u Novom Sadu je ukazao: u prvom rešenju od 23. 2. 2017. godine - da nije jasan opis krivičnog dela i da za Ajaza nije obezbeđen ovlašćeni prevodilac; $u$ drugom rešenju od 12. 4. 2017. godine - da se u pogledu prevoda nikako ne može raditi o sitnim greškama u pisanju, „već o greškama takve prirode koje osnovano dovode u pitanje razumevanje sadržine prevedenog teksta", ponavljajući da u komunikaciji s Ajazom nije obezbeđen ovlašćeni prevodilac; u trećem rešenju od 15. 11. 2017. godine - da iz prevoda nije jasno o kom se krivičnom delu radi i koji je turski krivični zakon primenjen, da naš sud nije mogao da ,na zvaničnom jeziku postupka izvrši uvid u spise dostavljene od strane R. Turske" i da za Ajaza nije obezbeđen ovlašćeni prevodilac. Iako bitnih promena u pogledu prevoda dokumentacije nije bilo, a Apelaciono javno tužilaštvo u Novom Sadu je predložilo ukidanje poslednjeg prvostepenog rešenja zbog toga što nije postupljeno u skladu sa nalozima drugostepenog suda u pogledu neadekvatnosti prevoda, Apelacioni sud u Novom Sadu je u svom četvrtom rešenju od 14. 12. 2017. godine prestao da pridaje bilo kakav značaj pitanju prevoda dokumentacije.

Nezavisno od pravne i faktičke prirode prevoda delova turskog Krivičnog zakona (čl. 314, 53, 62, 63, 68), iz poslednjih odluka Višeg suda u Šapcu i Apelacionog suda u Novom Sadu proizlazi da je Ajaz osuđen za krivično delo Naoružana organizacija iz čl. 314. st. 1. turskog Krivičnog zakona br. 5237. Posebno bi trebalo ukazati na protivrečnost ovoga sa navodima molbe za izručenje, potpisane 7. 12. 2016. godine od strane Republičkog tužioca u Dijarkbakiru, u kojoj se ističe da se radi o krivičnom delu „Pružanje smeštaja izvršiocima krivičnog dela na organizovani način".

Turski Krivični zakon br. 5237 donet je nakon izvršenja krivičnog dela za koje je Ajaz osuđen. To je konstatovano u rešenju Apelacionog suda u Novom Sadu Kž Kre. 30/17. od 15. 11. 2017. godine, ali je navedeno da, osim što se u molbi za izručenje i u dostavljenoj pravnosnažnoj presudi citiraju identične odredbe zakona koji je bio na snazi u vreme izvršenja krivičnog dela (čl. 168. st. 1. turskog Krivičnog zakona br. 765), prvostepeni sud nije na potpun $i$ celovit način utvrdio o kom se konkretno krivičnom delu radi. Drugim rečima, tada, a po našem mišljenju ni kasnije, nije bilo moguće izvesti zaključak o 
eventualnoj povredi čl. 7. st. 1. Evropske konvencije za zaštitu ljudskih prava i osnovnih sloboda, odnosno čl. 15. st. 1. Međunarodnog pakta o građanskim i političkim pravima, u kojima se propisuju načelo legaliteta, zabrana retroaktivnosti i dopušteni izuzeci.

Ovo pitanje je utoliko značajnije što je krivično delo iz čl. 314. st. 1. turskog Krivičnog zakona delimično blanketnog karaktera, jer upućuje na krivična dela iz poglavlja V i VI, čije izvršenje je pretpostavka za krivično delo za koje je Ajaz osuđen. Sudovi zamoljene države, međutim, nisu raspolagali prevodima poglavlja V i VI turskog Krivičnog zakona, kako onog koji je bio na snazi tempore criminis tako ni adekvatnih poglavlja onog koji je kasnije donet i ovde primenjen.

U svakom slučaju, u samoj odredbi čl. 314. st. 1. turskog Krivičnog zakona reč je o osnivanju ,organizacije” ili upravljanju „organizacijom”. U prvostepenoj presudi utvrđuje se da: „U političkom krilu organizacije za odgovorno lice i koordinatora izabran je Cevdet Ayaz zvani Ahmet." Takođe, utvrđuje se da se radi o Partiji oslobođenja Kurdistana - Revolucionarnoj partiji Kurdistana i da je Nacrtom programa definisano da se radi o nacionalnoj partiji oslobođenja i nezavisnosti Kurdistana, čiji cilj je, između ostalog: „,vođenje politike uzimajući u obzir državne, oblasne, ekonomske i vojne okolnosti". Neizbežan je, dakle, zaključak da je posredi političko krivično delo i delo koje ima odlike organizovanog kriminala. I komparativno krivično delo iz čl. 319. Krivičnog zakonika Republike Srbije spada u politička krivična dela i dela organizovanog kriminala (čini ga kreator ili pripadnik grupe ili organizovane kriminalne grupe radi protivustavne delatnosti).

Iako se za politička krivična dela ne odobrava izručenje, a u svom poslednjem rešenju Apelacioni sud u Novom Sadu je ispravno konstatovao da je za to pitanje nadležno Ministarstvo pravde, u rešenju ministra pravde br. 71301-05190/2016-08 od 15. 12. 2017. godine, ${ }^{12}$ kojim je dozvoljeno izručenje, u potpunosti je izostala ocena o kategoriji krivičnog dela i zaštićenom objektu, pa i o eventualnom odsustvu razloga za odbijanje izručenja zbog nepolitičke prirode krivičnog dela. Ovo ključno pitanje jednostavno je prećutano.

Dana 12. 4. 2017. godine na sednici veća pred Apelacionim sudom u Novom Sadu Ajaz je izneo da je prilikom prvog privođenja u Dijarbakiru u policiji dao izjavu koja je zabeležena na nekoliko stranica, da se izjava koju je potpisao sastojala od četiri reda teksta i sadržala njegovo priznanje da je član Revolucionarne partije Kurdistana, i da je tu izjavu potpisao nakon postupanja koje sadrži sve osobine torture.

\footnotetext{
${ }^{12}$ Ministarka pravde u to vreme bila je, a i sada je, gđa Nela Kuburović.
} 
U toku postupka pred organima Republike Srbije, 20. 10. 2017. godine Ajazova odbrana je pribavila i sudu dostavila presudu Evropskog suda za ljudska prava kojom je utvrđeno da je zadržavanje okrivljenog u policijskom pritvoru bez sudske kontrole prešlo granice trajanja pritvora koje bi bilo u skladu sa čl. 5. st. 3. Evropske konvencije. Evropski sud je prihvatio tvrdnje podnosilaca predstavke, a među njima i Ajaza, da im nije bilo dostupno pravo na efikasan i delotvoran pravni lek kojim bi mogli osporiti trajanje i zakonitost pritvaranja. U više predmeta Evropskog suda za ljudska prava zauzet je stav da je i samo držanje pritvorenika u neprikladnim uslovima suprotno čl. 3. Evropske konvencije, jer pobuđuje osećaj inferiornosti, poniženja, psihičke i fizičke patnje i opšteg umanjenja ljudskog dostojanstva, podobnog da slomi njegov fizički i moralni integritet. ${ }^{13}$

Nasuprot obavezi Republike Srbije, koja proizlazi iz odredbe čl. 3. Konvencije UN protiv torture i drugih surovih, neljudskih ili ponižavajućih kazni i postupaka, ni Ministarstvo pravde niti sud u postupku utvrđivanja pretpostavki za izručenje nisu se upuštali u pitanje da li postoji sumnja da će osuđeni, u slučaju vraćanja u Tursku, biti podvrgnut mučenju. Posebna obaveza ministra pravde, u skladu sa čl. 7. st. 3. ZMPPKS bila je da odluči, odnosno dâ mišljenje, o ispunjenju pretpostavke iz čl. 7. st. 1. t. 5. istog zakona koja podrazumeva da pružanje međunarodne pravne pomoći, između ostalog, ne bi povredilo javni poredak ili druge interese od suštinskog značaja za Republiku Srbiju. Kršenje međunarodnih obaveza koje je Srbija preuzela svakako povređuje i njen javni poredak i njene suštinske interese.

Prilikom donošenja odluke o izručenju zanemareno je i pitanje da li je Ajazu u Turskoj suđeno u odsustvu. A da mu jeste suđeno u odsustvu može se zaključiti iz presude i njegovih izjava pred sudom u Srbiji. Ministar pravde bio je u obavezi da ispita ovu tvrdnju, jer je, prema čl. 33. ZMPPKS, dužan da donese rešenje kojim ne dozvoljava izručenje ako u postupku suđenja u odsustvu licu čije se izručenje zahteva nisu bile ostvarene garancije pravičnog suđenja, pri čemu ima razloga za verovanje da te garancije zaista nisu bile obezbeđene. Takođe, u slučaju izručenja lica kome je suđeno u odsustvu, ministar pravde je morao da, u skladu sa čl. 16. t. 7. ZMPPKS, od države molilje pribavi garancije da će postupak biti ponovljen u prisustvu izručenog lica. Ministar pravde to nije učinio, niti je u rešenju o izručenju postavio takav uslov Turskoj.

Najzad, polazeći od navedene sudske prakse, može se smatrati da je o ispunjenju pretpostavki za izručenje odlučivao stvarno i mesno nenadležan sud.

${ }^{13}$ Peers v. Grčke, 28524/95; Sarigiannis v. Italije, 14569/05; Ibram v. Grčke, 39606/09, Alboreo v. Ferancuske, 51019/08; Stoleriu v. Rumunije, 5002/05. 


\section{ZAKLJUČAK}

I u sudskom i u upravnom postupku za izručenje Dževdeta Ajaza, Republika Srbija je povredila više obaveza koje ima po unutrašnjem i međunarodnom pravu. Sudski postupak primer je načina na koji prvostepeni sud uporno ignoriše i zakon i odluke drugostepenog suda, a drugostepeni sud izneverava sopstvene stavove, prvobitno pravno utemeljene i dosledne, da bi se, pod neposrednim spoljašnjim pritiskom ili predostrožnom podaničkom samoregulacijom, nasuprot domaćem i međunarodnom pravu, na kraju priklonio političkim interesima. Prvostepeni sud, koji je istrajno zanemarivao Ajazova osnovna prava, a sadržaj turskih zakona i presuda prihvatao bez adekvatnog prevoda, na improvizovan i aproksimativan način, na kraju je odneo ,pobedu” nad instanciono nadređenim sudom, iako nije udovoljio njegovim osnovnim primedbama i uputima. U ovom slučaju pravo je bilo podređeno interesima svedenim na aktuelne bilateralne aranžmane između Srbije i Turske. ${ }^{14}$

Ministar pravde, iako njegova nadležnost podrazumeva i politički pristup, nije oslobođen primene prava. Izručenje može da dozvoli samo na osnovu pravnosnažnog rešenja suda kojim se utvrđuje da su pretpostavke za izručenje ispunjene. Politički domet njegovih ovlašćenja ograničen je na mogućnost da i u takvom slučaju izručenje ne dozvoli. Ako ga dozvoli, ministar iz političkog prelazi na pravni teren, na kome su njegove obaveze striktno propisane zakonom.

Prva loša posledica za našu zemlju je, sama po sebi, pomenuta odluka Komiteta protiv torture. Ona je „moralne” prirode, jer pravnoj i pravosudnoj reputaciji naše zemlje, koja je inače veoma nisko rangirana, zadaje novi udarac.

Komitet je najpre utvrdio da je Konvencija povređena nepostupanjem po zahtevu da se sa izručenjem zastane dok se ne razmotri Ajazova pritužba. Nije prihvaćeno objašnjenje da je Ministarstvo pravde zahtev primilo 18. 12. 2017. godine kada je odluka o izručenju već bila doneta, budući da je do izručenja do-

${ }^{14} \mathrm{Ne}$ smemo smetnuti s uma da su te 2017. godine odnosi između Srbije i Turske bili na visokom prijateljskom nivou. Predsednik Srbije Vučić je u julu bio u Istanbulu na 22. naftnom kongresu i sa predsednikom Turske Erdoganom razgovarao o Turskom toku, a Erdogan je u oktobru bio u Beogradu. Tada mu je Vučić rekao da u Srbiji nikada neće imati one koji će praviti paktove s protivnicima legalno izabranih organa u Turskoj, i da mi ,nemamo ništa ni sa Gulenom, niti bilo kim drugim”, zbog čega ,nemojte ni da pomislite ili da sumnjate da Srbija može da učestvuje u bilo čemu što je protiv odluka koje su demokartskim putem donete u vašoj zemlji i protiv demokratski izabranih organa". Početkom maja 2018. Vučić je ponovo bio kod Erdogana i u govoru na tursko-srpskom Poslovnom forumu, pohvalio ocenu turskih medija da odnosi dve zemlje nikad nisu bili bolji, tj. da su onakvi kakvi su bili u vreme Kemala Ataturka i kralja Aleksandra. 
šlo 25. 12. 2017. godine, pa je bilo i vremena i mogućnosti da ono, u skladu sa zahtevom, bude odloženo. U odluci se navodi da, shodno čl. 22. st. 1. Konvencije, svaka država potpisnica priznaje nadležnost Komiteta da prima i razmatra pritužbe pojedinaca koji tvrde da su žrtve torture, čime implicitno preuzima i obavezu da sa Komitetom sarađuju u dobroj veri, tako što će mu omogućiti da delotvorno, tj. bez štete za žrtvu, razmotri pritužbe koje su mu podnete.

Osnovno ogrešenje o Konvenciju Komitet je našao u povredi čl. 3. Za razliku od stava izraženog u odgovoru naše države da je Tursku uvrstila na listu sigurnih država porekla i sigurnih trećih država, Komitet je imao suprotno gledište, uzimajući u obzir efekte vanrednog stanja u Turskoj (ukinutog tek u julu 2018. godine), koje je prouzrokovalo teške povrede ljudskih prava na stotine hiljada ljudi, uključujući proizvoljna lišenja prava na rad i slobodu kretanja, mučenja, hapšenja i povrede prava na slobodu udruživanja i izražavanja. Konstatovao je da organi Srbije nisu utvrdili da li je osuđujuća presuda protiv podnosioca predstavke bila zasnovana na njegovom priznanju iznuđenom mučenjem. Najzad, ukazao je na činjenicu da u vreme kada je Ajaz bio izručen Turskoj, naši organi još nisu imali adekvatno prevedene spise u vezi sa osuđujućom presudom protiv njega. Komitet je ostavio Srbiji rok od 90 dana da ga obavesti o merama koje je preduzela, a u koje spada i odgovarajuća briga o uslovima pod kojima Ajaz izdržava kaznu u Turskoj.

Druga posledica biće materijalne prirode. Odnosiće se na obavezu naše države da Ajazu pruži obeštećenje. Na takvu obavezu podseća i Komitet, pominjući da obeštećenje uključuje i adekvatnu naknadu štete zbog prouzrokovanih fizičkih i psihičkih patnji.

Treća posledica je unutrašnje prirode i tiče se pitanja da li će biti statusnih i drugih konsekvenci za one koji su odgovorni za propuste, a pre svega za ministarku pravde i nestručne, instrumentalizovane ili direktno instruisane sudije, ili će takve konsekvence, što pretpostavljamo da će se i dogoditi, potpuno izostati. 